\title{
FIRE AFFECTS ECOPHYSIOLOGY AND COMMUNITY DYNAMICS OF CENTRAL WISCONSIN OAK FOREST REGENERATION ${ }^{1}$
}

\author{
Peter B. ReICH \\ Department of Forestry, University of Wisconsin-Madison, Madison, Wisconsin 53706 USA \\ MarC D. ABrams ${ }^{2}$ \\ College of Natural Resources, University of Wisconsin-Stevens Point, \\ Stevens Point, Wisconsin 54481 USA \\ David S. Ellsworth, Eric L. Kruger, and TOM J. TABOne \\ Department of Forestry, University of Wisconsin-Madison, Madison, Wisconsin 53706 USA
}

\begin{abstract}
In order to understand better the ecophysiological differences among competing species that might influence competitive interactions after, or in the absence of, fire, we examined the response to fire of four sympatric woody species found in intermediatesized gaps in a 30-yr-old mixed-oak forest in central Wisconsin. Selected blocks in the forest were burned in April 1987 by a low-intensity controlled surface fire. The fire had significant effects during the following growing season on community structure, foliar nutrient concentrations, and photosynthesis. Acer rubrum seedling density declined by $70 \%$ following the fire, while percent cover increased several-fold in Rubus allegheniensis. In general, leaf concentrations of $\mathrm{N}, \mathrm{P}$, and $\mathrm{K}$ were increased by the fire in all species, although the relative enhancement decreased as the growing season progressed. Daily maximum photosynthetic rates were 30-50\% higher in burned than unburned sites for Prunus serotina, Quercus ellipsoidalis, and $R$. allegheniensis, but did not differ between treatments for $A$. rubrum. Mean sunlit photosynthetic rates and leaf conductances were stimulated by the burn for all species, with the greatest enhancement in photosynthesis measured in $Q$. ellipsoidalis. Leaf gas exchange in $R$. allegheniensis was most sensitive to declining leaf water potential and elevated vapor pressure gradient, with $Q$. ellipsoidalis the least sensitive. Fire had no discernable effect on water status of these plants during a year of relatively high rainfall. In comparison with other species, $A$. rubrum seedlings responded negatively after fire-both in terms of survival/reproduction (decline in the number of individuals) and relative leaf physiological performance. Fire enhanced the abundance of $R$. allegheniensis and the potential photosynthetic performance of $R$. allegheniensis, $P$. serotina, and particularly $Q$. ellipsoidalis. We conclude that post-fire stimulation of net photosynthesis and conductance was largely the result of enhanced leaf $\mathrm{N}$ concentrations in these species.

Key words: Acer; community; competition; ecophysiology; fire; forest gap; leaf conductance; $n u-$ trients; photosynthesis; Prunus; Quercus; regeneration; Rubus; Wisconsin.
\end{abstract}

\section{INTRODUCTION}

A dramatic expansion of woody vegetation has occurred at the prairie-forest ecotone in North America since European settlement began in the mid-1800s (Kucera 1960, Pyne 1983, Abrams 1986). Some researchers have suggested that the forest expansion resulted from decreased fire frequency and intensity compared to that during Native American occupation (Gleason 1913, Sauer 1950, Penfound 1962, Lorimer 1983, Abrams 1985). Oak (Quercus) species were the primary constituents of these newly forested areas in the Midwest United States (Rice and Penfound 1959, Curtis 1959, Kucera 1960). In a further succession,

\footnotetext{
'Manuscript received 20 April 1989; revised 12 November; accepted 22 January 1990.

2 Present address: School of Forest Resources, Pennsylvania State University; University Pārk, Pennsylvania 16802 USA.
}

oaks are now frequently being replaced by more shadetolerant species, perhaps also due to continued low fire frequency (Wuenscher and Valiunas 1967, Grimm 1983, Nigh et al. 1985, Abrams 1986).

Since hardwood forest fires in the upper Midwest generally have little effect on larger trees (White 1983, Abrams 1988), differential regeneration survival and seedling invasion among species probably determine successional trajectories on burned and unburned sites. However, little is known about potential ecophysiological differences among competing species that might influence competitive interactions after, or in the absence of, fire.

In other ecosystems (e.g., coniferous forest, prairie, chaparral), fire usually causes increased nutrient availability for a period of time that may vary from weeks to years depending on several factors (intensity of fire, fuel supply, climate, etc.; Raison 1979). Consequently, 
woody plants on burned plots usually have higher foliar nutrient concentrations than similar species on unburned plots, with potential ramifications for growth and allocation (James and Smith 1977, Ohmann and Grigal 1979, DeSouza et al. 1986). Shoot growth rates for resprouts on burned sites were higher than on unburned sites in chaparral (Radosevich and Conard 1980, DeSouza et al. 1986), and photosynthetic rates in several chaparral species have been observed to be greater in burned than unburned plots, especially early in the growing season (Oechel and Hastings 1983, DeSouża et al. 1986). However, due to sampling limitations, these data showing enhanced photosynthesis were presented for only one date for each of three species and for three dates in a fourth species. Thus, a sufficient data base on post-fire leaf gas exchange is not available to predict responses in midwestern hardwood forests.

In the present study, we examined the response to fire of four sympatric woody species (Acer rubrum, Prunus serotina, Quercus ellipsoidalis, Rubus allegheniensis) found in intermediate-size gaps in a 30-yr-old mixed-oak forest in central Wisconsin. The four species differ widely in their successional status. At one extreme Rubus is an early successional shrub that characteristically invades disturbed sites. In contrast, Acer is a mid-to-late-successional tree species that typically establishes abundant regeneration in the understory of dry oak forests in the Lake States (Curtis 1959). Quercus and Prunus are early-to-mid-successional species that are generally considered as intermediate between Rubus and Acer (Fowells 1965). Tree regeneration in gaps largely determines future stand structure in eastern hardwood forests under non-catastrophic conditions (Lorimer 1989), and cool surface fires are the most common fire type occurring in these forests as well as the fire type used in prescribed burning (Donaghue and Johnson 1975, Abrams 1988).

Population changes for each species were monitored following a controlled, spring surface fire, and seasonal patterns of leaf morphology, nutrient status, and physiological performance for each species were compared in adjacent burned vs. unburned plots. We hypothesized that greater foliar nutrient levels in burned plots would provide a mechanism for enhanced photosynthesis. Both field photosynthetic capacity and average "realized" photosynthesis were considered of importance in terms of interpreting photosynthetic response to post-fire conditions. Daily and seasonal patterns of net photosynthesis result from (1) maximum photosynthetic capacity, and (2) transitory conditions that cause "realized" photosynthesis to be less than the potential maximum. Therefore, the study was designed first to test whether potential post-fire changes in nutrient availability result in alterations of leaf chemistry and thus in photosynthetic capacity. Second, the study also examined the extent to which any potential enhancement of photosynthesis was realized over daily and seasonal time courses when a number of other factors might also be limiting to photosynthesis. We also hypothesized that fast-growing shade-intolerant species such as Rubus would show the most positive physiological response following fire, while shade-tolerant Acer would show the least.

\section{MATERIALS AND MethodS}

The study was carried out at the Schmeeckle Reserve of the University of Wisconsin-Stevens Point, in Stevens Point, Wisconsin. Four blocks ( 0.6 to 1.4 ha) were located in a 30-yr-old hardwood stand on Plainfield soil, with half of each block randomly assigned to a burned or unburned treatment. Plainfield soil is characterized as a deep, excessively drained, medium-tocoarse sand that is medium-to-strongly acidic (Otter and Fiala 1978). For data pooled across all blocks, northern pin oak ( $Q$. ellipsoidalis) represented $55 \pm$ $13 \%$ (mean $\pm 1 \mathrm{SE}$ ) of the overstory individuals, followed in rank by red maple (Acer rubrum) $(12 \pm 5 \%)$, white oak (Q. alba) (12 $\pm 3 \%$ ), paper birch (Betula papyrifera) $(11 \pm 6 \%)$, bigtooth aspen (Populus grandidentata $)(7 \pm 5 \%)$, trembling aspen $(P$. tremuloides $)$ $(3 \pm 2 \%)$, and jack pine (Pinus banksiana), white pine $(P$. strobus) and black cherry (Prunus serotina) $(\leq 1 \%$ each). Burn treatment plots were subjected to a surface fire on 9 April 1987. The fire began at 1030 and ended at 1200 central standard time (CST). Relative humidity and air temperature during the burn were $\approx 24 \%$ and $24^{\circ} \mathrm{C}$, respectively. Wind was out of the northwest at $<3 \mathrm{~km} / \mathrm{h}$. Mean flame height was $<0.3 \mathrm{~m}$, and mean rate of spread for the headfire was $3.3 \mathrm{~m} / \mathrm{min}$, and we therefore considered this to be a low intensity fire.

In 1986 all trees ( $\geq 10 \mathrm{~cm}$ in diameter at breast height [dbh]) were surveyed in each of the eight half-blocks. In addition, 10 plot centers were established systematically along transects in each half-block. Centered around each of those points, seedlings ( $\leq 1.5 \mathrm{~m}$ tall) were counted, and shrub and herb cover was estimated in small $\left(5 \mathrm{~m}^{2}\right)$ subplots, while saplings $(>1.5 \mathrm{~m}$ tall and $<10 \mathrm{~cm} \mathrm{dbh}$ ) were counted in larger plots $\left(10 \mathrm{~m}^{2}\right)$. For purposes of this paper the term "seedling" is used for all trees $\leq 1.5 \mathrm{~m}$ tall, regardless of whether the stem is a true seedling, a root collar sprout, or a root sucker. Canopy cover of shrubs and herbs was estimated and grouped according to classes outlined by Daubenmire (1959). The midpoints of the six classes $(2.5,15.0,37.5$, $62.5,85$, and $97.5 \%$ ) were used to compute species coverage. These surveys were made in July or August of both 1986 (pre-burn) and 1987 (post-burn). Due to high variation in population data, results are presented for all trends significant at $P<.10$.

Physiological measurements were made in the growing season after the fire. Because of the need to avoid significant defoliation of individual plants, measurements for each species were made using a population of individuals within burned vs. unburned plots. Measurements were made in only the highest light mi- 
TABLE 1. Abundance of young trees and shrubs before and after a surface fire. Data are means \pm 1 SE.

\begin{tabular}{|c|c|c|}
\hline \multicolumn{3}{|c|}{ A. Seedlings of clonal stems ( $\leq 1.5 \mathrm{~m}$ tall $)$} \\
\hline & \multicolumn{2}{|c|}{$\begin{array}{l}\text { Seedlings or clonal stems } \\
\text { (no./ha) }\end{array}$} \\
\hline & Pre-burn (1986) & Post-burn (1987) \\
\hline Acer rubrum* & $10600 \pm 2344$ & $2850 \pm 576$ \\
\hline tremuloides $\dagger$ & $450 \pm 334$ & $1300 \pm 634$ \\
\hline Prunus serotinat & $28250 \pm 14853$ & $18500 \pm 9866$ \\
\hline $\begin{array}{l}\text { Quercus alba } \\
\text { Quercus }\end{array}$ & $550 \pm 179$ & $450 \pm 286$ \\
\hline ellipsoidalis & $2300 \pm 304$ & $2450 \pm 426$ \\
\hline
\end{tabular}

B. Rubus and other shrubs (percent cover in $5-\mathrm{m}^{2}$ plots) Shrub cover

(\%)

\begin{tabular}{lcr}
\cline { 3 - 3 } & Pre-burn (1986) & Post-burn (1897) \\
\hline Rubus & & \\
$\quad$ allegheniensis* & $9.8 \pm 3.5$ & $51.1 \pm 6.5$ \\
Other shrubs & $6.5 \pm 1.0$ & $8.1 \pm 1.6$ \\
Total shrub* & $16.3 \pm 3.4$ & $59.2 \pm 7.3$
\end{tabular}

$* P<.05, \dagger P<.10$ (significance of differences between abundances in the two years).

croenvironments: in intermediate-size gaps ranging from about 250 to $500 \mathrm{~m}^{2}$. The most abundant woody species in these gaps were Acer rubrum, Prunus serotina, Quercus ellipsoidalis, and Rubus allegheniensis. On five days during the growing season, leaf structure and chemistry and diurnal patterns of plant water status and leaf gas exchange were measured for plants of all four species from burned and unburned plots. These plants averaged between 0.5 and $1.0 \mathrm{~m}$ in height and the tree species were roughly between 3 and 7 yr old. As far as was possible, we chose to make measurements on days that were relatively cloud-free and with moderate summertime temperatures, with measurement days spaced more or less regularly throughout the growing season. On one day rain showers interrupted the course of diurnal measurements.

Plant water status was measured with a pressure chamber (Ritchie and Hinckley 1975), and leaf gas exchange was measured with two units of a portable gas analyzer and cuvette system (Analytical Development Company, Ltd., Hoddesdon, England) that measures both $\mathrm{CO}_{2}$ and water vapor exchange using a differential mass balance approach (Walters and Reich 1989). For gas exchange measurements, leaves were arbitrarily defined as "sunlit" (if receiving any direct solar irradiance) or "shaded" (if receiving no direct solar irradiance), as observed at the time of measurement. Sunlit and shaded leaves had photosynthetic photon flux densities (PPFD) $>350 \mu \mathrm{mol} \cdot \mathrm{m}^{-2} \cdot \mathrm{s}^{-1}$ or $<240 \mu \mathrm{mol} \cdot \mathrm{m}^{-2} \cdot \mathrm{s}^{-1}$, respectively. Maximum photosynthetic rates observed under field conditions such as those of this study are $\approx 90 \%$ of those measured under optimal steady-state controlled conditions (D. S. Ellsworth and P. B. Reich, unpublished manuscript) and thus are a useful index of potential photosynthetic capacity (Field and Mooney 1986). For this study, daily maximum net photosynthesis and leaf conductance were calculated as the average of the five highest measurements per day. A subsample of leaves was collected after gas exchange and water-status measurements for analyses of area, dry mass, and nutrient concentrations. A. rubrum had both relatively few leaves per plant and low numbers of seedlings in large burned gaps, so physiological sampling of this species was done less frequently and intensively than for the other three species.

Leaf areas were measured with a LI-COR Area Meter (LI-COR, Lincoln, Nebraska). Foliar nutrient concentrations were analyzed by the University of Wisconsin Soil and Plant Analysis Laboratory. Total leaf $N$ concentrations were measured using microKjeldahl techniques, and the other nutrients were measured by inductively coupled plasma emission spectrometry. Unless otherwise noted, nutrient concentrations are expressed on a dry mass basis.

The 1987 growing season in Stevens Point, Wisconsin, was characterized by above-average temperatures and average rainfall (National Oceanic and Atmospheric Administration, personal communication). Rainfall totaled $44 \mathrm{~cm}$ from 1 May until 30 September, with at least $5 \mathrm{~cm}$ of rain received in each month.

Data were analyzed using the SAS package (SAS Institute 1985). Analyses of variance and regression analyses were primarily used, but analysis of covariance was used in analyzing photosynthetic response to treatment and species for shaded leaves, with photon flux density the covariate $(P<.001)$. Multifactorial analyses of variance were used to assess response of leaf gas exchange to combined factors such as irradiance, leaf water potential, and vapor pressure gradient (VPG). In order to analyze the relationship between net photosynthesis and leaf nitrogen concentration, we pooled data from all days, but used data only from before midday for Prunus, Quercus, and Rubus, since, in general, afternoon photosynthetic rates were lower. Because of the limited number of total observations available for $A$. rubrum, all data were used.

\section{RESULTS}

\section{Community data}

No first-year mortality or aboveground dieback of overstory trees occurred in the burned plots. The fire top-killed (caused stem dieback) 67 to $100 \%$ of the Prunus serotina, Betula papyrifera, and Populus grandidentata saplings, but none of the $Q$. ellipsoidalis saplings. In the year before the fire, $P$. serotina and $A$. rubrum accounted for about 67 and $25 \%$, respectively, of the woody seedling population. Following the fire, the seedling population in burned blocks decreased on average by $\approx 75$ and $35 \%$ for $A$. rubrum and $P$. serotina, respectively (Table $1 \mathrm{~A}$ ). Numbers of $Q$. ellipsoidalis and $Q$. alba seedlings were essentially unchanged after 
TABLE 2. Specific leaf mass $\left(\mathrm{g} / \mathrm{m}^{2}, \vec{X} \pm 1 \mathrm{SE}\right)$ of four species on $5 \mathrm{~d}$ in 1987 . Within species there were no differences in burned vs. unburned plots, so data are pooled across these treatments. Average sample size per species per day $=32$, except for day $210(n=6)$ and A. rubrum $(n=8)$.

\begin{tabular}{|c|c|c|c|c|c|}
\hline & \multicolumn{5}{|c|}{ Day of year } \\
\hline & 155 & 181 & 210 & 217 & 258 \\
\hline Acer rubrum & $\ldots$ & $40.3 \pm 2.2$ & $\ldots$ & $40.8 \pm 4.2$ & $47.8 \pm 1.5$ \\
\hline Prunus serotina & $31.5 \pm 1.7$ & $39.4 \pm 1.6$ & $38.9 \pm 3.2$ & $42.1 \pm 1.4$ & $46.2 \pm 1.7$ \\
\hline Quercus ellipsoidalis & $46.5 \pm 3.6$ & $55.3 \pm 1.6$ & $55.9 \pm 2.2$ & $55.2 \pm 1.9$ & $57.6 \pm 2.0$ \\
\hline Rubus allegheniensis & $34.2 \pm 1.3$ & $40.0 \pm 1.7$ & $44.2 \pm 3.3$ & $44.4 \pm 1.9$ & $46.0 \pm 1.7$ \\
\hline
\end{tabular}

the fire, and there was also a $200 \%$ increase in the population of $P$. tremuloides seedlings. Measurements of shrubs and herbs in 1986 and 1987 indicate an increase in Rubus cover (from 10 to $50 \%$ ) following the fire (Table 1B). Carex pensylvanica cover also increased substantially after burning (data not shown).

\section{Leaf structure and nutrient status}

In general, specific leaf mass (SLM) of all species on all plots increased from the beginning to the end of the growing season (Table 2). There was no significant difference in SLM between burned and unburned plots in any species. Quercus always had significantly $(P<$ .001) greater SLM than every other species, with no significant differences observed among the other three species.

Averaged over the growing season, foliar concentrations of several nutrients were significantly $(P<.05)$ higher in burned than unburned plots for all or some species (Table 3). In Acer and Prunus foliar N and $\mathrm{K}$ levels were higher on burned plots, in Rubus $\mathrm{N}$ and $\mathrm{P}$ were higher, and in Quercus $\mathrm{N}, \mathrm{P}, \mathrm{K}$, and $\mathrm{Mg}$ were elevated. In both burned and unburned plots Rubus and Prunus had the highest leaf $\mathrm{N}$ concentrations on average, with Quercus intermediate and Acer lowest. However, due to greater SLM in Quercus, leaf N per unit leaf area was greatest in that species, intermediate in Prunus and Rubus, and lowest in Acer (data not shown).

Species and treatments differed in the seasonal dynamics of leaf nutrient status, with the fire apparently producing a large pulse of available nutrients in the period soon after the burn (Fig. 1). In early June (day 155), foliar N concentrations in Prunus and Quercus were $\approx 35 \%$ greater in burned than unburned plots (Fig. $1 \mathrm{~A})$. During the remainder of the year, leaf $\mathrm{N}$ was $\approx 10$ $20 \%$ greater in burned than unburned plots. These differences were significant $(P<.05)$ for both species on all sampling dates, except for Prunus on day 181. In Rubus leaf $\mathrm{N}$ remained essentially unchanged over the season in unburned plots while decreasing continuously in burned plots, resulting in the following contrast: in burned plots leaf $\mathrm{N}$ was $50 \%$ greater on day $155,25 \%$ greater on day 181 , not significantly different on days 210 or 217 , and $10 \%$ less on day 258 than in unburned plots. Differences in leaf $\mathrm{N}$ between burned and unburned plots also diminished over the growing season in $A$. rubrum.

In Quercus, increases $(P<.05)$ in foliar $\mathrm{P}$ concentrations in burned plots were large (80-1 10\%) and consistent over the growing season (Fig. 1B). In Acer, Pru$n u s$, and Rubus, stimulation of leaf $\mathrm{P}$ in burned plots was greatest $(25-50 \%)$ early in the season, but decreased over time, and by September no differences in leaf $P$ remained between burned and unburned plots. In all four species, leaf $\mathrm{K}$ concentrations were higher in burned than unburned plots early in the growing season (data not shown). In Acer, Quercus, and Prunus these differences disappeared by the end of the season, while in Rubus leaf $\mathrm{K}$ concentrations became lower in burned than unburned plots by that time. Since SLM did not differ significantly among plants in burned and unburned plots, the above patterns hold for nutrient concentrations expressed on an area or dry mass basis.

TABLE 3. Nutrient concentrations (mean \% dry mass) pooled across the growing season for four species in burned and unburned plots in central Wisconsin. Data were equally weighted for days $155,181,217$, and 258 , except for $A$. rubrum, for which no data were available on day 155 . Values within a column with the same superscript letter are not significantly different ( $P<.05$, Tukey's studentized range test).

\begin{tabular}{|c|c|c|c|c|c|c|}
\hline & & $\mathrm{N}$ & $\mathbf{P}$ & $\mathrm{K}$ & $\mathrm{Ca}$ & $\mathrm{Mg}$ \\
\hline Acer rubrum & $\begin{array}{l}\text { Burned } \\
\text { Unburned }\end{array}$ & $\begin{array}{l}2.02^{\mathrm{c}} \\
1.73^{\mathrm{d}}\end{array}$ & $\begin{array}{l}0.11^{\mathrm{cd}} \\
0.10^{\mathrm{cd}}\end{array}$ & $\begin{array}{l}0.58^{\mathrm{c}} \\
0.47^{\mathrm{d}}\end{array}$ & $\begin{array}{l}0.83^{\mathrm{ab}} \\
0.91^{\mathrm{a}}\end{array}$ & $\begin{array}{l}0.26^{c} \\
0.25^{c}\end{array}$ \\
\hline Prunus serotina & $\begin{array}{l}\text { Burned } \\
\text { Unburned }\end{array}$ & $\begin{array}{l}2.87^{\mathrm{a}} \\
2.44^{\mathrm{b}}\end{array}$ & $\begin{array}{l}0.14^{\mathrm{bc}} \\
0.12^{\mathrm{bcd}}\end{array}$ & $\begin{array}{l}0.91^{\mathrm{a}} \\
0.68^{\text {bd }}\end{array}$ & $\begin{array}{l}0.76^{\mathrm{ab}} \\
0.79^{\mathrm{ab}}\end{array}$ & $\begin{array}{l}0.37^{\mathrm{b}} \\
0.38^{\mathrm{b}}\end{array}$ \\
\hline Quercus ellipsoidalis & $\begin{array}{l}\text { Burned } \\
\text { Unburned }\end{array}$ & $\begin{array}{l}2.51^{\mathrm{b}} \\
2.09^{\mathrm{c}}\end{array}$ & $\begin{array}{l}0.18^{\mathrm{a}} \\
0.09^{\mathrm{d}}\end{array}$ & $\begin{array}{l}0.70^{\mathrm{b}} \\
0.59^{\mathrm{c}}\end{array}$ & $\begin{array}{l}0.52^{\mathrm{c}} \\
0.59^{\mathrm{c}}\end{array}$ & $\begin{array}{l}0.24^{\mathrm{c}} \\
0.18^{\mathrm{d}}\end{array}$ \\
\hline Rubus allegheniensis & $\begin{array}{l}\text { Burned } \\
\text { Unburned }\end{array}$ & $\begin{array}{l}2.74^{\mathrm{a}} \\
2.41^{\mathrm{b}}\end{array}$ & $\begin{array}{l}0.21^{\mathrm{a}} \\
0.13^{\mathrm{bc}}\end{array}$ & $\begin{array}{l}0.76^{\mathrm{ab}} \\
0.82^{\mathrm{ab}}\end{array}$ & $\begin{array}{l}0.72^{\mathrm{b}} \\
0.67^{\mathrm{bc}}\end{array}$ & $\begin{array}{l}0.45^{\mathrm{a}} \\
0.51^{\mathrm{a}}\end{array}$ \\
\hline Range of SE & & $0.03-0.09$ & $0.01-0.02$ & $0.03-0.08$ & $0.02-0.09$ & $0.01-0.03$ \\
\hline
\end{tabular}


TABLE 4. Three measures of net photosynthesis and leaf conductance for four species on burned and unburned plots in central Wisconsin pooled over all sampling dates (means $\pm 1 \mathrm{SE}$ ). Daily maximum rates averaged for the five highest observations per day. Values within a column with the same superscript letters are not significantly different $(P<.05$, Tukey's studentized range test).

\begin{tabular}{|c|c|c|c|c|c|c|c|}
\hline \multirow[b]{2}{*}{ Species } & \multirow[b]{2}{*}{ Treatment } & \multicolumn{2}{|c|}{ Daily maximum } & \multicolumn{2}{|c|}{ Mean sunlit } & \multicolumn{2}{|c|}{ Mean shaded } \\
\hline & & $\begin{array}{l}\text { Photo- } \\
\text { synthesis } \\
(\mu \mathrm{mol} \cdot \\
\left.\mathrm{m}^{-2} \cdot \mathrm{s}^{-1}\right)\end{array}$ & $\begin{array}{c}\text { Leaf } \\
\text { conductance } \\
\text { (mmol } \\
\left.\mathrm{m}^{-2} \cdot \mathrm{s}^{-1}\right)\end{array}$ & $\begin{array}{l}\text { Photo- } \\
\text { synthesis } \\
(\mu \mathrm{mol} \cdot \\
\left.\mathrm{m}^{-2} \cdot \mathrm{s}^{-1}\right)\end{array}$ & $\begin{array}{c}\text { Leaf } \\
\text { conductance } \\
(\mathrm{mmol} \\
\left.\mathrm{m}^{-2} \cdot \mathrm{s}^{-1}\right)\end{array}$ & $\begin{array}{l}\text { Photo- } \\
\text { synthesis } \\
(\mu \mathrm{mol} \cdot \\
\left.\mathrm{m}^{-2} \cdot \mathrm{s}^{-1}\right)\end{array}$ & $\begin{array}{c}\text { Leaf } \\
\text { conductance } \\
(\mathrm{mmol} \cdot \\
\left.\mathrm{m}^{-2} \cdot \mathrm{s}^{-1}\right)\end{array}$ \\
\hline Acer rubrum & $\begin{array}{l}\text { Burned } \\
\text { Unburned }\end{array}$ & $\begin{array}{l}3.8 \pm 0.2^{\mathrm{e}} \\
4.0 \pm 0.2^{\mathrm{e}}\end{array}$ & $\begin{array}{l}166 \pm 41^{\mathrm{e}} \\
149 \pm 52^{\mathrm{e}}\end{array}$ & $\begin{array}{l}3.5 \pm 0.2^{\mathrm{d}} \\
3.0 \pm 0.2^{\mathrm{c}}\end{array}$ & $\begin{array}{l}147 \pm 10^{\mathrm{e}} \\
116 \pm 7^{\mathrm{f}}\end{array}$ & $\begin{array}{l}1.1 \pm 0.2^{\mathrm{a}} \\
0.9 \pm 0.2^{\mathrm{a}}\end{array}$ & $\begin{array}{l}123 \pm 12^{\mathrm{c}} \\
121 \pm 10^{\mathrm{c}}\end{array}$ \\
\hline Prunus serotina & $\begin{array}{l}\text { Burned } \\
\text { Unburned }\end{array}$ & $\begin{array}{l}8.0 \pm 0.4^{\mathrm{bc}} \\
5.9 \pm 0.4^{\mathrm{d}}\end{array}$ & $\begin{array}{l}430 \pm 71^{\mathrm{bc}} \\
263 \pm 60^{\mathrm{dc}}\end{array}$ & $\begin{array}{l}5.8 \pm 0.3^{\mathrm{a}} \\
4.4 \pm 0.2^{\mathrm{bc}}\end{array}$ & $\begin{array}{l}296 \pm 19^{\mathrm{b}} \\
163 \pm 10^{\mathrm{dc}}\end{array}$ & $\begin{array}{l}1.0 \pm 0.1^{\mathrm{a}} \\
1.1 \pm 0.1^{\mathrm{a}}\end{array}$ & $\begin{array}{l}166 \pm 10^{b} \\
131 \pm 9^{c}\end{array}$ \\
\hline $\begin{array}{l}\text { Quercus } \\
\quad \text { ellipsoidalis }\end{array}$ & $\begin{array}{l}\text { Burned } \\
\text { Unburned }\end{array}$ & $\begin{array}{l}9.0 \pm 0.3^{\mathrm{ab}} \\
5.7 \pm 0.4^{\mathrm{d}}\end{array}$ & $\begin{array}{l}446 \pm 48^{\mathrm{b}} \\
282 \pm 51^{\mathrm{cdc}}\end{array}$ & $\begin{array}{l}6.3 \pm 0.3^{\mathrm{a}} \\
3.9 \pm 0.2^{\mathrm{cd}}\end{array}$ & $\begin{array}{l}298 \pm 22^{\mathrm{b}} \\
183 \pm 11^{\mathrm{d}}\end{array}$ & $\begin{array}{l}1.0 \pm 0.1^{\mathrm{a}} \\
0.9 \pm 0.1^{\mathrm{a}}\end{array}$ & $\begin{array}{l}167 \pm 12^{\mathrm{b}} \\
127 \pm 11^{\mathrm{c}}\end{array}$ \\
\hline $\begin{array}{l}\text { Rubus } \\
\quad \text { allegheniensis }\end{array}$ & $\begin{array}{l}\text { Burned } \\
\text { Unburned }\end{array}$ & $\begin{array}{l}9.3 \pm 0.4^{\mathrm{a}} \\
6.4 \pm 0.4^{\mathrm{cd}}\end{array}$ & $\begin{array}{l}805 \pm 91^{\mathrm{a}} \\
381 \pm 47^{\mathrm{bcd}}\end{array}$ & $\begin{array}{l}5.8 \pm 0.3^{\mathrm{a}} \\
4.5 \pm 0.2^{\mathrm{b}}\end{array}$ & $\begin{array}{l}401 \pm 32^{\mathrm{a}} \\
249 \pm 15^{\mathrm{c}}\end{array}$ & $\begin{array}{l}0.5 \pm 0.1^{\mathrm{b}} \\
1.0 \pm 0.1^{\mathrm{a}}\end{array}$ & $\begin{array}{l}252 \pm 14^{\mathrm{a}} \\
185 \pm 14^{\mathrm{b}}\end{array}$ \\
\hline
\end{tabular}

in either Rubus or Acer. Daytime minimum leaf water potential decreased $(P<.05)$ for all species on burned and unburned plots from early to late season.

\section{Gas exchange}

Rates of net photosynthesis pooled from all days and all times of day for sunlit leaves (PPFD $>350 \mu \mathrm{mol}$. $\left.\mathrm{m}^{-2} \cdot \mathrm{s}^{-1}\right)$ were significantly greater $(P<.01)$ in burned than unburned plots for all species (Table 4). There was also a significant interaction $(P<.05)$ between species and treatment (burn vs. no burn), indicating a differential ability among species to respond to postfire conditions. Quercus had the greatest fire-induced relative and absolute stimulation of mean photosynthesis $\left(60 \%\right.$ and $2.3 \mu \mathrm{mol} \cdot \mathrm{m}^{-2} \cdot \mathrm{s}^{-1}$, respectively), followed by both Prunus and Rubus $(\approx 30 \%$ and 1.4 $\left.\mu \mathrm{mol} \cdot \mathrm{m}^{-2} \cdot \mathrm{s}^{-1}\right)$, and Acer $\left(15 \%\right.$ and $\left.0.5 \mu \mathrm{mol} \cdot \mathrm{m}^{-2} \cdot \mathrm{s}^{-1}\right)$. Using the more limited amount of data available for massbased rather than area-based photosynthesis, results of all analyses were similar (data not shown).

There were significant differences in mean sunlit leaf conductance values between treatments and species, but there was no significant interaction (Table 4). In all species, plants on burned plots had higher mean leaf conductances than on unburned plots. Leaf conductance was significantly greater in Rubus than in all other species, with Prunus and Quercus also having significantly greater conductance than Acer. Increases in conductance on burned plots were $80 \%$ in Prunus, $60 \%$ in Quercus and Rubus, and 30\% in Acer. For Acer, Prunus, and Rubus the relative percent stimulation in mean leaf conductance on burned plots was twice as great as the stimulation in photosynthesis, while increases in the two parameters were similar for Quercus. In all species, transpiration rates at all times of day were significantly higher for plants on burned than unburned plots (data not shown), despite no differences in leaf water potential. This suggests that soil-to-leaf hydraulic conductance was greater in burned than unburned plants.
Significant species and treatment effects were observed for gas exchange rates of "shaded" leaves as well. Mean values of photosynthetic photon flux density (PPFD) for shaded leaves used in gas exchange measurements were not significantly different among treatments or species. Net photosynthetic rates were significantly lower for shaded Rubus leaves on burned plots than for any other species-treatment combination (Table 4). For conductance of shaded leaves, all species but Acer had higher rates on burned than unburned plots. Rubus had higher conductance in shaded leaves than the other species, with Acer significantly lower than Prunus and Quercus on the burned plots.

Daily maximum net photosynthesis and leaf conductance, averaged among sampling dates, were significantly $(P<.05)$ higher on burned than unburned plots for Quercus, Prunus, and Rubus, but not Acer (Table 4). In Quercus and Rubus on burned plots, the stimulation of maximum photosynthesis was almost $50 \%$ compared to unburned plots, with stimulation of $30 \%$ for Prunus and 0\% for Acer, respectively. Among species in both burned and unburned plots, maximum photosynthesis and leaf conductance were least in Acer. Daily maximum photosynthesis in Rubus was not significantly higher than in Quercus, while maximum leaf conductance was $40-75 \%$ higher in Rubus, suggesting lower water use efficiency in Rubus than in Quercus under optimal field conditions.

At all times of day in Prunus, Quercus, and Rubus, average rates of leaf conductance and photosynthesis for sunlit leaves were higher in burned than unburned plots, although differences tended to be greatest early in the day, especially for Prunus and Rubus (Fig. 3). In Acer, there was a trend for gas exchange rates to be higher around midday in burned than unburned plots, otherwise there were no differences. In Prunus and $R u$ bus gas exchange rates were highest in the morning and generally declined throughout the day, with this pattern being displayed least by Quercus.

Within each species there was no significant difference between the leaf $\mathrm{N}$ and net photosynthesis rela- 

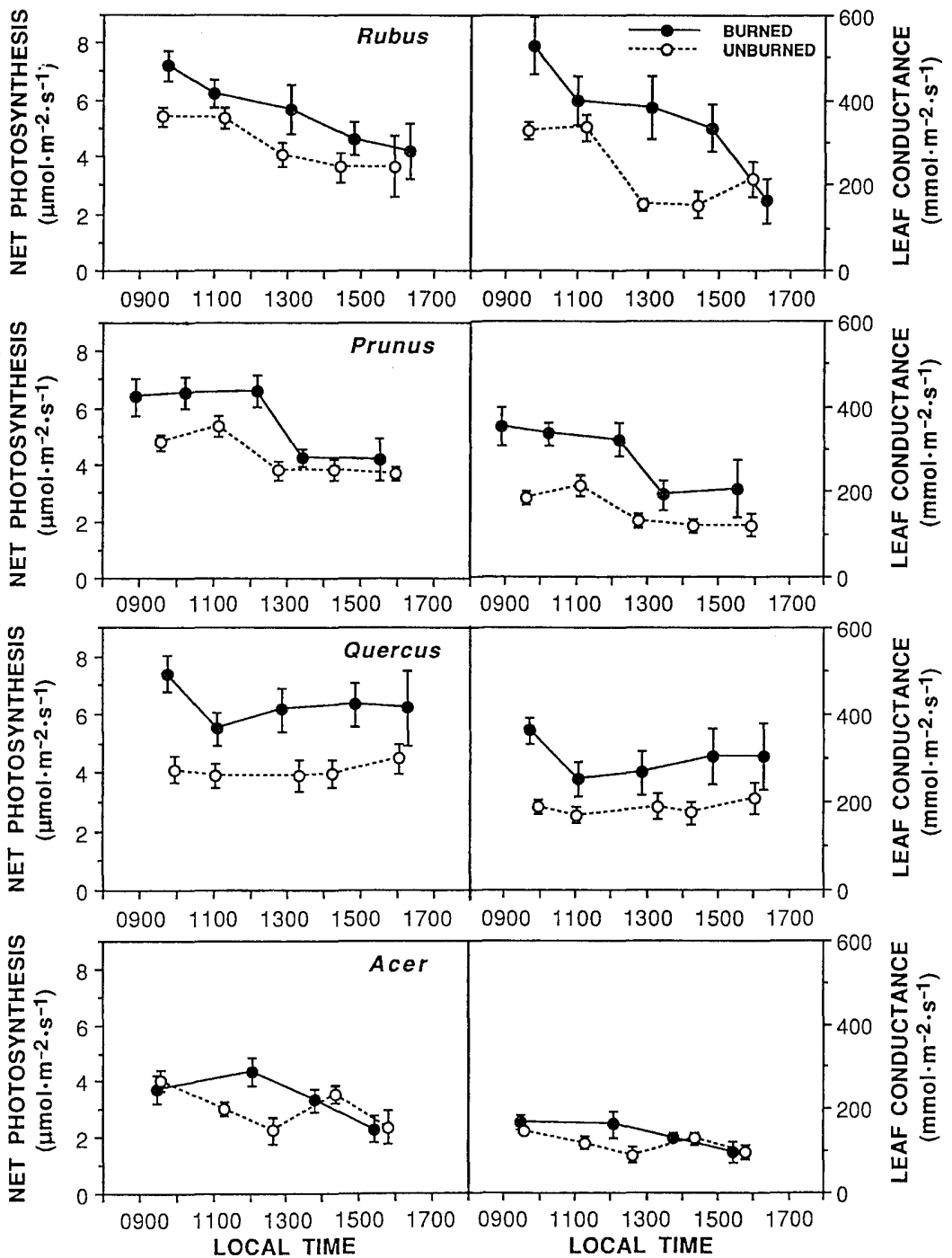

FIG. 3. Mean ( $\pm 1 \mathrm{SE}$ ) diurnal patterns of gas exchange of sunlit leaves for four species on burned $(\bullet)$ and unburned $(O)$ forest gaps in central Wisconsin. Time in United States central daylight savings time.

tionship for data from burned and unburned plots, so data from both treatments were pooled for presentation herein. For each species, there was a significant linear relationship between leaf $\mathrm{N}$ and net photosynthesis with both expressed on an area basis (Table 5). The slope of the relationship was steepest in Quercus, followed in order by Prunus, Rubus, and Acer. The relationship between leaf $\mathrm{N}$ and net photosynthesis was generally poorer or not significant when both $\mathrm{N}$ and photosynthesis were expressed on a dry-mass basis (data not shown).

Since leaf $\mathrm{N}$ was higher on burned than unburned plots (Table 3 ) and had similar positive effects on net photosynthetic rates in all plots (Table 5), we conclude that the post-fire stimulation of net photosynthesis was largely a result of enhanced leaf $\mathrm{N}$ concentrations. Sev-

TABLE 5. Relationship between net area-based photosynthesis (Ps, $\left.\mu \mathrm{mol} \cdot \mathrm{m}^{-2} \cdot \mathrm{s}^{-1}\right)$ and leaf nitrogen $\left(\mathrm{N}_{\text {arca }}, \mathrm{g} / \mathrm{m}^{2}\right)$ for four species in forest gaps in central Wisconsin. Since there were no significant differences within species in this relationship between burned and unburned plots, data are pooled within species in statistical analyses.

\begin{tabular}{llcc}
\hline \hline & Regression equations & $P$ & $r^{2}$ \\
\hline Acer rubrum & Ps $=0.6+3.41\left(\mathrm{~N}_{\text {area }}\right)$ & $<.05$ & 0.30 \\
Prunus serotina & $\mathrm{Ps}=1.6+4.13\left(\mathrm{~N}_{\text {ara }}\right)$ & $<.001$ & 0.41 \\
Quercus ellipsoidalis & $\mathrm{Ps}=-1.1+5.36\left(\mathrm{~N}_{\text {arca }}\right)$ & $<.001$ & 0.54 \\
Rubus allegheniensis & Ps $=2.6+3.80\left(\mathrm{~N}_{\text {area }}\right)$ & $<.01$ & 0.27 \\
\hline
\end{tabular}




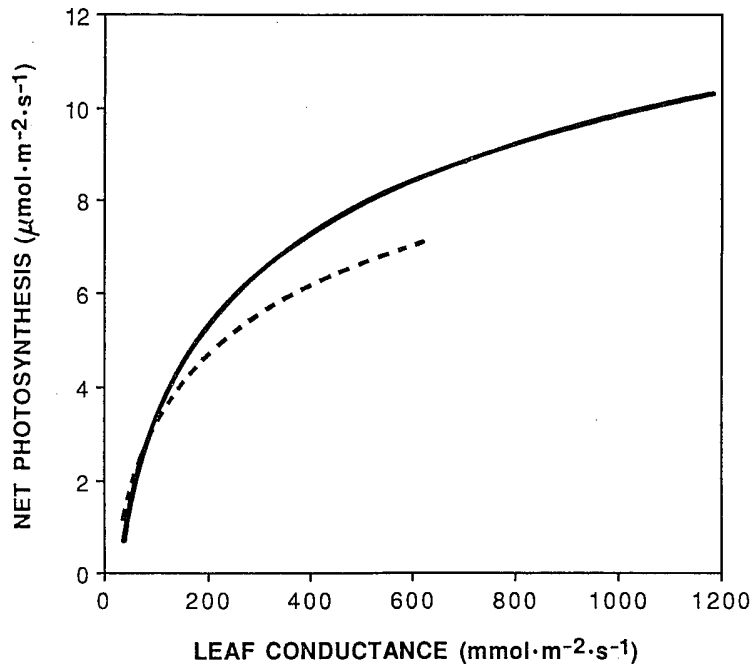

FIG. 4. Relationship between net photosynthesis (Ps) and leaf conductance $(g)$ for leaves on burned $(-)$ and unburned $(--)$ sites. Regressions are derived from all sunlit data obtained before 1300 . There was no species $\times$ treatment interaction upon the photosynthesis vs. conductance relationship; hence, data for all species are pooled within treatments. Equation for unburned sites is Ps $=-6.54+2.13(\ln g), r^{2}=0.58$, $P<.0001$. Equation for burned sites is $\mathrm{Ps}=-9.52+2.80$ $(\ln g), r^{2}=0.52, P<.0001$. The difference in slope between the two equations is significant at $P=.01$.

eral other lines of evidence support this idea. Inasmuch as mass-based leaf $\mathrm{N}$ concentration appears to largely determine maximum mass-based photosynthesis among and within species (Field and Mooney 1986), we ask whether seasonal patterns in maximum massbased net photosynthesis in burned vs. unburned plots were similar to those for leaf $\mathrm{N}$ concentration. The results (Fig. 1) appear to largely support this contention: Quercus and Prunus exhibited higher photosynthesis and leaf $\mathrm{N}$ in burned plots throughout the season, while Acer and Rubus exhibited higher photosynthesis and leaf $\mathrm{N}$ in burned plots early in the season, with differences between burned and unburned plots disappearing over time. Plants on burned plots also had greater net photosynthetic rates for a given level of leaf conductance than those on unburned plots (Fig. 4).
There was no interaction between species and treatment on this relationship. Greater net photosynthesis for a given level of leaf conductance likely results from greater biochemical carbon dioxide fixation capacity, which is related to concentrations of nitrogenous compounds such as RuBP carboxylase (Field and Mooney 1986).

Both vapor pressure gradient (VPG) and leaf water potential appeared to limit gas exchange in sunlit leaves. There were no mean differences among species or treatments in microenvironment (e.g., VPG) for the gas exchange data set. Response of leaf gas exchange to leaf water potential or VPG did not differ among burned and unburned plots, so data were pooled by species. Both Rubus and Prunus showed a significant $(P<.01)$ linear decrease in leaf conductance as a function of declining leaf water potential, with a steeper slope for Rubus than for Prunus (Table 6). Conductance in Quercus and Acer was not significantly affected by leaf water potential. Rubus had a significant $(P<.01)$ negative response of area-based photosynthesis to declining water potential, but the other three species did not (Table 6).

Leaf gas exchange rates were negatively correlated with increasing VPG in all species (Table 6). The slopes of these responses were greatest in Rubus and least in Quercus and Prunus. Since VPG and leaf water potential are usually highly correlated, it is not possible from these analyses to determine whether leaves were directly responding to VPG, water status, or both. However, for Quercus, and to a lesser extent Prunus and Acer, significant responses to VPG were observed at levels of leaf water potential that apparently did not cause stomatal response.

\section{Discussion}

A surface fire in early spring had significant effects during the following growing season on community composition and ecophysiology of regeneration in a central Wisconsin hardwood forest. The effects of fire on seedling ecophysiology were a result of changes in nutrient availability and/or root-shoot balance. Important differences in ecophysiological response among species were observed as well, perhaps related to differences in their successional status. The effects of fire

TABLE 6. Relationships between leaf conductance $(g)$ and net photosynthesis (Ps) and either leaf water potential $(\psi)$ or vapor pressure gradient (VPG). Data are pooled from burned and unburned plots, since no differences in response were observed between these groups. Significant relationships are noted by ${ }^{* *} P<.01$ and ${ }^{*} P<.05$. Units: $g:\left(\mathrm{mmol}^{\circ} \cdot \mathrm{m}^{-2} \cdot \mathrm{s}^{-1}\right) ; \mathrm{PS}:(\mu \mathrm{mol}$. $\left.\mathrm{m}^{-2} \cdot \mathrm{s}^{-1}\right) ; \psi:(\mathrm{MPa}) ; \mathrm{VPG}$ : $(\mathrm{kPa})$. All data are for sunlit leaves (photosynthetic photon flux density $>350 \mu \mathrm{mol}^{-} \mathrm{m}^{-2} \cdot \mathrm{s}^{-1}$ ).

\begin{tabular}{|c|c|c|c|c|}
\hline & \multicolumn{2}{|c|}{$\begin{array}{l}g \text { and Ps as a function of } \\
\text { leaf water potential }(\psi)\end{array}$} & \multicolumn{2}{|c|}{$\begin{array}{c}g \text { and Ps as a function of } \\
\text { vapor pressure gradient (VPG) }\end{array}$} \\
\hline & $g$ & Ps & $g$ & Ps \\
\hline $\begin{array}{l}\text { Acer rubrum } \\
\text { Prunus serotina } \\
\text { Quercus }\end{array}$ & $g=455^{\text {NS }}+112 \psi^{* *}$ & $\begin{array}{l}\text { NS } \\
\text { NS }\end{array}$ & $g=366-87.6 \mathrm{VPG}^{*}$ & $\begin{array}{l}\mathrm{Ps}=5.7-1.8 \mathrm{VPG}^{*} \\
\mathrm{Ps}=6.5-1.1 \mathrm{VPG}^{*}\end{array}$ \\
\hline $\begin{array}{l}\text { ellipsoidalis } \\
\text { Rubus }\end{array}$ & NS & NS & $g=368-87.9 \mathrm{VPG}^{*}$ & $\mathrm{Ps}=7.3-1.4 \mathrm{VPG}^{*}$ \\
\hline allegheniensis & $g=759+252 \psi^{* *}$ & Ps $=9.57+2.6 \psi^{* *}$ & $g=571-160.8 \mathrm{VPG}^{* *}$ & $\mathrm{Ps}=8.6-2.3 \mathrm{VPG}^{* *}$ \\
\hline
\end{tabular}


on community composition were primarily due to differential mortality and reproduction between species.

In terms of nutrient cycling processes, many basic cations (e.g., P, K, Ca, Mg, and $\mathrm{Na}$ ) are released when the vegetation and surface organic layer are consumed by fire, and therefore increase in the soil (Ahlgren and Ahlgren 1960). The situation with $\mathrm{N}$ is more complex because it is easily volatilized during fire. There is increasing evidence, however, that microbial $\mathrm{N}$ fixation and transformation (mineralization) are stimulated by post-fire conditions (e.g., increased soil moisture, soil temperature, nutrient availability, and $\mathrm{pH}$ ), which may increase soil N availability (cf. Christensen 1973, St. John and Rundel 1976). An increase in soil nutrients often increases certain foliar nutrients in the post-burn vegetation. Following the 1971 Little Sioux fire in Minnesota, $\mathrm{P}, \mathrm{Ca}$, and $\mathrm{Mg}$ concentrations were higher in vegetation from burned than unburned stands (Ohmann and Grigal 1979). In southern Ontario, N, P, K, Ca, and $\mathrm{Mg}$ were $24-42 \%$ higher in trembling aspen leaves on burned compared to unburned areas (James and Smith 1977). Forest shrubs in burned larch-Douglasfir forests in Montana had significantly higher concentrations of $\mathrm{N}, \mathrm{P}, \mathrm{Na}, \mathrm{Fe}$, and $\mathrm{Mn}$ than shrubs in the unburned controls (Stark and Steele 1977).

Similar results were observed in our Wisconsin study. In general, leaf concentrations of $\mathrm{N}, \mathrm{P}$, and $\mathrm{K}$ were increased in all study species by the fire, although this enhancement tended to decrease as the growing season progressed. This could be explained by a limited period of increased nutrient availability in the rooting zone after fire, or a growth stimulation that in essence diluted the nutrients within a greater amount of plant tissue, or both. An initial pulse followed by a decrease in nutrient levels in foliage and surface soil with time after fire has been previously reported (Christensen 1977 , Covington and Sackett 1984, Knapp 1985).

Mineral nutrition often has a pronounced effect on leaf physiological function. Studies involving a wide variety of plant species have demonstrated a positive relationship between $\mathrm{N}$ concentrations in leaves and gas exchange rates (Longstreth and Nobel 1980, Gulmon and Chu 1981, Field and Mooney 1986). Moreover, low concentrations of leaf $\mathrm{P}, \mathrm{K}$, and $\mathrm{Mg}$ have also been correlated with low photosynthetic rates (Longstreth and Nobel 1980, Rao et al. 1987, Reich and Schoettle 1988). In the present study, field photosynthetic capacity (defined as maximum observed values) and maximum leaf conductance were significantly increased in burned plots for all species except Acer. Since burned and unburned plants did not differ in their leaf $\mathrm{N}$ : photosynthesis relationships, we attribute much of the gain in field photosynthetic capacity in burned plants directly to elevated leaf $\mathrm{N}$ concentrations (Field and Mooney 1986). Differences between burned and unburned plants in seasonal patterns of leaf $\mathrm{N}$ and photosynthesis and in photosynthesis : leaf conductance relationships also support this view. Increased soil-to-leaf hydraulic conductance may also contribute to increased photosynthesis if leaf conductance increases along with hydraulic conductance (Reich and Hinckley 1989). Post-fire vegetation in chaparral and prairie ecosystems has increased leaf gas exchange rates relative to unburned vegetation, and this has been attributed as well to fire-induced improvements in nutrient status and water relations (Oechel and Hastings 1983, Knapp 1985, DeSouza et al. 1986).

As mentioned earlier (Results: Gas exchange), both maximum potential photosynthesis (as above) and the lower rates "realized" over the course of the day should be considered in evaluating field photosynthetic performance. All four species tended to have maximum gas exchange rates in the morning (Fig. 3), with rates declining more or less throughout the day. Mean photosynthetic rates and leaf conductances (for sunlit leaves) were greater in the burned plots for all species, with Quercus showing a significantly greater enhancement of photosynthesis than the other species. It is interesting that Acer had significantly higher average net photosynthesis and leaf conductance on burned than unburned plots, despite not having an increase in maximum photosynthesis or leaf conductance. This was apparently a result of $A$. rubrum on burned plots maintaining relatively high gas exchange rates during midday (Fig. 3), when unburned $A$. rubrum plants were experiencing depressions in gas exchange rates typically associated with midday water stress (Hinckley et al. 1978). For all four species, the results suggest that enhanced photosynthetic capacity and/or the maintenance of relatively high photosynthetic rates throughout the day should contribute to greater carbon gain in leaves of burned than unburned plants. If increases in mean daily carbon gain were similar in relative magnitude to increases in mean photosynthetic rates (15$60 \%$ ), this would be an important contribution to plant carbon balance.

Within species, photosynthesis-leaf $\mathrm{N}$ relationships in this study were stronger on area than on mass bases. This is in contrast to the data of Field and Mooney (1986) among species largely from high-light environments, but agrees with recent results from our laboratory for temperate and tropical species in shaded or partially shaded environments (D. S. Ellsworth and P. B. Reich, unpublished manuscript; P. B. Reich, M. Walters, D. S. Ellsworth, and C. Uhl, unpublished manuscript). In understory or gap environments, light-harvesting may be an important competitive feature, and thus area-based photosynthetic potential may be more important, and more tightly coupled with $\mathrm{N}$, than massbased photosynthetic potentials in such environments.

Stimulation of photosynthesis and leaf conductance in burned plots probably resulted largely from greater foliar $\mathrm{N}$ concentrations, but altered root-shoot dynamics should be considered as well. Most of the seedlings in the burned gaps in this study were top-killed by the 
fire, with the result that the vast majority of aboveground stems in burned plots were 1987 sprouts, while those in unburned plots were largely original stems, or sprouts from previous years or from 1987. Comparisons of leaf function between young northern red oaks (Q. rubra) that were stem-pruned and those that were not (Kruger and Reich 1989, E. L. Kruger and P. B. Reich, unpublished manuscript) show certain similarities to differences between the burned and unburned individuals in this study. Pruned individuals had higher photosynthetic rates and leaf conductances than unpruned red oak plants, yet they had similar water deficits. The enhanced photosynthesis of pruned red oak appeared to be a result of alteration in root : leaf source/ sink relations. The similarities between the results of the two studies suggest that altered root: shoot relations following top-kill probably contributed partially to some of the differences observed between burned and unburned plants in this study.

Can changes in foliar nutrient concentrations also be attributed to changes in root: shoot dynamics? Although pruned red oak plants did have a minimal increase in leaf nutrient concentration in contrast to unpruned plants (E. L. Kruger and P. B. Reich, unpublished manuscript), the increase was considerably less than the differences observed between burned and unburned plants in this study. Also, the seasonal timing of burned vs. unburned plot nutritional differences (Fig. 1) and prior documented evidence for post-fire nutrient pulses (e.g., Christensen 1977, Knapp 1985) suggest that most of the increase in leaf nutrient concentration observed in this study resulted from effects of fire on nutrient availability, rather than on altered root : shoot relations due to top-killing of plants by the fire.

Fire had minimal effect on water status of the plants during the study year. However, 1987 was a relatively rainy summer and significant, pre-dawn, plant water deficits did not occur. In a dry summer, such as in the following year 1988, when pre-dawn water deficits throughout Wisconsin were often -1 to $-2 \mathrm{MPa}$ lower than in 1987 (D. S. Ellsworth, E. L. Kruger, and P. B. Reich, personal observation), potential differences due to treatments and species could be important. Under drought conditions, differences in root: shoot allocation and hence in soil-to-leaf hydraulic conductance between burned and unburned plots might be important in terms of development of significant, pre-dawn, plant water stress. The "water-spending" strategy of Rubus may be advantageous during years when rainfall is plentiful, such as the study year, but its drought sensitivity may prove disadvantageous during dry years or on more xeric sites.

At the community level, Rubus had a positive response to fire and abundance of Acer and Prunus seedlings a negative response, with abundance of Quercus seedlings unaffected. Differential mortality, sprouting ability, and rates of revegetation were likely responsible for these differences. Stems of Quercus saplings were uniformly resistant to the fire, but heavy aboveground dieback was observed in saplings of other species. Leaf and whole-plant physiological response also differed among species. Elevation of foliar N, P, and $\mathrm{K}$ was briefest in Rubus and longest in Quercus, especially for $P$. The increased leaf nutrient levels and altered root: shoot relations of seedlings on burned plots resulted in increased average photosynthetic rates for sunlit leaves in all species. However, this response was significantly greater in oak than in the other species. This may have resulted from a steeper response of photosynthesis to increasing leaf $\mathrm{N}$ in oak and to greater tolerance of VPG and plant water deficits in this species. Prunus and Rubus in particular were sensitive to VPG and leaf water potential, and under conditions of high VPG or low water status these species were not able to maintain high photosynthetic rates. Thus, interactions with other stresses appear to temporally limit the ability of individual Prunus and Rubus plants to photosynthetically profit from post-burn conditions, in comparison with Quercus.

How can one assess the relative ecological importance of fire-induced changes in individual plant performance vs. changes in populations of seedlings/ sprouts? Strength of statistical significance may not be representative of relative biological significance (Anonymous reviewer of this paper, personal communication). For instance, the statistical significance of changes in net photosynthesis was greater than for changes in population or cover. However, fire-induced changes in net photosynthesis ranged from 15 to $60 \%$ in the four species, while changes in population or cover ranged from $-70 \%$ in $A$. rubrum to $+400 \%$ in $R$. allegheniensis. Given the current data set and the experimental design, it is impossible to determine whether changes in populations or in performance of individuals will have more impact on woody plant dynamics following fire in these forest habitats (or in what ways they might interact). However, the results of this study do suggest that both may have significant influence on woody plants in such systems.

In summary, many of the differences among species observed in this study were consistent with their purported differences in successional status, fire resistance, and performance on disturbed sites. Taken as a whole, Acer, a later successional species, responded most negatively following fire, both in terms of survival/reproduction (decline in the number of individuals) and in relative leaf physiological performance of seedlings/ sprouts in a comparative sense. Numbers of Rubus stems responded most positively to the post-burn gap environment, whereas the number of stems of Prunus declined somewhat, and Quercus remained unchanged. Characteristic of being the most opportunistic and early successional species studied, Rubus maintained greater leaf conductance than the other species, but it was also most sensitive to decrease in leaf water potential and increased VPG. Quercus, considered the 
most fire and drought resistant of the species, exhibited greater daily maximum and mean net photosynthesis on burned vs. unburned sites and was the least sensitive species to decreases in water status. Prunus was intermediate among the species in terms of survival and physiological function following fire.

\section{ACKNOWLEDGMENTS}

We thank A. Kanikula for assistance in the laboratory and R. Nordheim for advice on statistical analysis. Financial support by the College of Agricultural and Life Sciences, University of Wisconsin-Madison, and the United States Department of Agriculture (McIntire-Stennis WIS03020 and CSRS 86-FSTY-9-0222) is gratefully acknowledged.

\section{Literature Cited}

Abrams, M. D. 1985. Fire history of oak gallery forests in a northeast Kansas tallgrass prairie. American Midland Naturalist 114:188-191.

- 1986. Historical development of gallery forests in northeast Kansas. Vegetatio 65:29-37.

- 1988. Effects of prescribed fire on woody vegetation in a gallery forest understory in northeastern Kansas. Transactions of the Kansas Academy of Science 91:63-70.

Ahlgren, I. F., and C. E. Ahlgren. 1960. Ecological effects of forest fires. Botanical Review 26:483-533.

Christensen, N. L. 1973. Fire and the nitrogen cycle in California chaparral. Science 181:66-68.

- 1977. Fire and soil-plant nutrient relations in a pine-wiregrass savanna on the coastal plain of North Carolina. Oecologia (Berlin) 31:27-44.

Covington, W. W., and S. S. Sackett. 1984. The effects of a prescribed burn in southwestern ponderosa pine on organic matter and nutrients in woody debris and forest floor. Forest Science 30:183-192.

Curtis, J. T. 1959. The vegetation of Wisconsin. University of Wisconsin Press, Madison, Wisconsin, USA.

Daubenmire, R. 1959. A canopy coverage method of vegetational analysis. Northwest Science 33:43-66.

DeSouza, J., P. A. Silka, and S. D. Davis. 1986. Comparative physiology of burned and unburned Rhus laurina after chaparral wildfire. Oecologia (Berlin) 71:63-68.

Donoghue, L. R., and V. J. Johnson. 1975. Prescribed burning in the North Central States. United States Department of Agriculture Forest Service, North Central Forest Experiment Station Research Paper NC-111.

Field, C., and H. A. Mooney. 1986. The photosynthesisnitrogen relationship in wild plants. Pages $25-55$ in T. J. Givnish, editor. On the economy of plant form and function. Cambridge University Press, New York, New York, USA.

Fowells, H. A. 1965. Silvics of forest trees of the United States. United States Department of Agriculture Forest Service Agricultural Handbook 271.

Gleason, H. A. 1913. The relation of forest distribution and prairie fires in the middle west. Torreya 13:173-181.

Gulmon, S. L., and C. C. Chu. 1981. The effects of light and nitrogen on photosynthesis, leaf characteristics, and dry matter allocation in the chaparral shrub, Diplacus aurantiacus. Oecologia (Berlin) 49:207-212.

Grimm, E. C. 1983. Chronology and dynamics of vegetation change in the prairie-woodland region of southern Minnesota. New Phytologist 93:311-350.

James, T. D. W., and D. W. Smith. 1977. Short-term effects of surface fire on the biomass and nutrient standing crop of Populus tremuloides in southern Ontario. Canadian Journal of Forest Research 7:666-679.

Knapp, A. K. 1985. Effect of fire and drought on the eco- physiology of Andropogon gerardii and Panicum virgatum in a tallgrass prairie. Ecology 66:1309-1320.

Kruger, E. L., and P. B. Reich. 1989. Comparative growth and physiology of stem-pruned and unpruned northern red oak. Page 302 in G. Rink and C. Budelsky, editors. Proceedings of Seventh Central Hardwood Conference, March 5-8, 1989, Carbondale, Illinois. United States Forest Service General Technical Report NC-132.

Kucera, C. L. 1960. Forest encroachment in native prairie. Iowa State Journal of Science 34:635-640.

Longstreth, D. J., and P. S. Nobel. 1980. Nutrient influences on leaf photosynthesis. Plant Physiology 65:541-543.

Lorimer, C. G. 1983. Eighty-year development of northern red oak after partial cutting in mixed-species Wisconsin forest. Forest Science 29:371-383.

- 1989. Relative effects of small and large disturbances on temperate hardwood forest structure. Ecology 70:565-567.

Nigh, T. A., S. G. Pallardy, and H. E. Garrett. 1985. Sugar maple-environment relationships in the River Hills of central Ozark Mountains of Missouri. American Midland Naturalist 114:235-251.

Oechel, W. C., and S. J. Hastings. 1983. The effects of fire on photosynthesis in chaparral resprouts. Pages 274-285 in F. J. Kruger, D. T. Mitchell, and J. U. M. Jarvis, editors. Ecological studies. Volume 43. Mediterranean-type ecosystems. Springer-Verlag, Berlin, Germany.

Ohmann, L. F., and D. F. Grigal. 1979. Early revegetation and nutrient dynamics following the 1971 Little Sioux forest fire in northeastern Minnesota. Forest Science Monograph 21:1-80.

Otter, A. J., and W. D. Fiala. 1978. Soil Survey of Portage County, Wisconsin. (United States Department of Agriculture.) United States Government Printing Office, Washington, D.C., USA.

Penfound, W. T. 1962. The savannan concept in Oklahoma. Ecology 43:774-775.

Pyne, S. J. 1983. Indian fires. Natural History 3:6-11.

Radosevich, S. R., and S. G. Conard. 1980. Physiological control of chamise shoot growth after fire. American Journal of Botany 67:1442-1447.

Raison, R. J. 1979. Modifications of the soil environment by vegetation fires with particular reference to nitrogen transformations: a review. Plant and Soil 51:73-108.

Rao, I. M., R. E. Sharp, and J. S. Boyer. 1987. Leaf magnesium alters photosynthetic response to low water potentials in sunflower. Plant Physiology 84:1214-1219.

Reich, P. B., and T. M. Hinckley. 1989. Influence of predawn water potential and soil-to-leaf hydraulic conductance on maximum daily leaf conductance in two oak species. Functional Ecology 3:719-726.

Reich, P. B., and A. W. Schoettle. 1988. Role of phosphorus and nitrogen in photosynthetic and whole plant carbon gain and nutrient use efficiency in eastern white pine. Oecologia (Berlin) 77:25-33.

Rice, E. L., and W. T. Penfound. 1959. The upland forests of Oklahoma. Ecology 40:593-608.

Ritchie, G. A., and T. M. Hinckley. 1975. The pressure chamber as an instrument of ecological research. Advances in Ecological Research 9:165-254.

SAS Institute. 1985. SAS user's guide: statistics, version 5, S. P. Joyner, editor. SAS Institute, Cary, North Carolina, USA.

Sauer, C. O. 1950. Grassland climax, fire, and man. Journal of Range Management 3:16-21.

Stark, N., and R. Steele. 1977. Nutrient content of forest shrubs following burning. American Journal of Botany 64 : 1218-1224.

St. John, T. V., and P. W. Rundel. 1976. The role of fire as a mineralizing agent in a Sierran coniferous forest. Oecologia (Berlin) 25:35-45. 
Walters, M. B., and P. B. Reich. 1989. Response of Ulmus americana seedlings to varying nitrogen and water status. I. Photosynthesis and growth. Tree Physiology 5:159-172. White, A. S. 1983. The effects of thirteen years of annual prescribed burning in a Quercus ellipsoidalis community in Minnesota. Ecology 64:1081-1085.
Wuenscher, J. E., and A. J. Valiunas. 1967. Presettlement forest composition of the River Hills region of Missouri. American Midland Naturalist 78:487-495. 